\title{
THE EFFECTIVENESS OF ECLECTIC METHOD IN TEACHING WRITING ENGLISH OF RECOUNT TEXT FOR THE EIGHT GRADE STUDENTS OF SMPN 1 KERUAK
}

\author{
Suparman \\ Sekolah Tinggi Ilmu Tarbiyah Palapa Nusantara Lombok Nusa Tenggara Barat
}

\begin{abstract}
The aim of the study was to examine the effectiveness of eclectic method to improve students' writing skill at the eighth grade students of SMP Negeri 1 Keruak, focusing on (1) Is eclectic method effective in writing skill at the eighth grade students of SMP Negeri 1 Keruak in the academic year 2016-2017? and (2) How is the effectiveness of the eclectic method to improve students' writing skill at the eighth grade students of SMP Negeri 1 Keruak in the academic year 2016-2017?. The design of this research was a pre-experimental pre-test and post-test research. It means this research only applied the eclectic method to the experimental group that consisted of 36 students. The sample of the study was taken by using cluster random sampling technique. In gaining pre-test and post-test data, the students required to do the individual task in writing the monolog text of recount based on the material that was learnt before. Then the pretest and post-test data was analyzed by using descriptive statistics and Paired Sample t-test to test the hypothesis. Having collected and calculated the data by using descriptive statistics, it was found out that descriptive statistic results showed that the mean score of the pre-test was 7.21 while the mean of the post-test was 9.25. The result of hypothesis testing by using Paired-Sample t-test was $\mathrm{t}_{(27)}=11.68$ at $p$ $=.000$. It was lower than .05 so it means that the null hypothesis (Ho) was rejected and the alternative hypothesis $(\mathrm{Ha})$ was accepted. In other word that the use of eclectic method was significantly effective in writing skill to the eighth grade students of SMP Negeri 1 Keruak in the academic year 2016-2017.
\end{abstract}

Keywords: Eclectic method, teaching writing, recount text

\section{Introduction}

Language is defined as anything which can be written, spoken, shown or otherwise communicated among people. It is an instrument of human communication, either spoken or written, consisting of the use of words in a structured and conventional way. Language is the most complex form of communication. Language is important because it is a symbolic communication system that is learned instead of biologically inherited. An advantage of human 
language is that it is a learned symbolic communication system that is infinitely flexible. Language is obviously a vital tool. Not only it is a means of communicating thoughts and ideas, but it forges friendships, cultural ties, and economic relationships. Throughout history, many events reflected on the importance of language. It shapes thoughts and emotions, determines one's perception of reality.

English as one of international languages which are used as a medium of communication, meanwhile according to the background of the English lesson in the School Based Curriculum (KTSP) it is stated that English is a tool of communication in oral and written. To communicate ${ }^{1}$ is the understanding and expressing the information, thought, feeling and to develop knowledge, technology and culture. The ability of communication in a complete sense $\mathrm{e}^{2}$ is the capability in case of discourse competence in understanding or producing oral or written text which are produced through listening, speaking, reading, and writing.

That are the skills will be used in responding and conveying the text in society daily life. Thus, the English subject is directed to develop those four language skills to provide the graduate of the students who are able to communicate in English beside gaining the discourse competence at a certain level of literacy. The levels of the literacy are performance, functional, informational, and epistemic. The target of the gaining English literacy at Junior High School is the level of functional literacy, means that by using English the students are able to use the target language to fulfill the need of daily life such as to read newspaper, manual, and direction. In other side the general objective of English learning at Junior High Schools are $\left.{ }^{3}: 1\right)$

To develop students' communicative competence oral or written to gain a certain literacy level. 2 ) To be conscious to the reality of English in developing the nation competition in the global era. 3) To develop student's understanding about the relationship of the language and culture. Meanwhile, the stated competency standard for eight class of junior high school writing part, is to express the meaning in written functional text in the form of short functional text of descriptive and recount monolog text to interact for the sake of environmental interaction. The basic

\footnotetext{
${ }^{1}$ Lampiran 2 Permendiknas No.22 tahun 2006, Jakarta,Mendiknas, 7 Juni 2006. No.36.277

${ }^{2}$ Ibid.

3 Ibid., 278.
} 
competencies are ${ }^{4}:$ 1) To express the meaning in the form of simple short written functional text in environmental interaction. 2)

To express the meaning and the rhetoric step in the form of simple short essay accurately and acceptable specific in environmental interaction. English is not only take a central role to develop student's intellectual, social, and emotional, but also it is needed to support the successful of the other subject matter. In addition, English is very important to be learned .

The importance role of English is due to one of the main necessities in learning English subject is the development of the four basic skills of language, which are listening, speaking, reading and writing. Writing is a productive skill to produce language as an activity to response to something read or listened.

Orwig ( 1998 ) differentiates the difference characteristic both of productive skills between speaking and writing as follows ${ }^{5}:$ 1) Performance, it means oral language tends to be produced in a real word, while written language is permanent, it means that the written text, is able to read whenever the reader would like to read it at any time as possible. 2) Production time, it means that written text need planning, reviewing, and revising which need a lot of time for the writers to complete the writing ready to be read. 3) Distance, which means the time and space which shared context between writer and reader. 4) The devices that occur on spoken language in enhancing messages through stress, intonation, pitch, volume, pausing, etc, that is orthography.

Writing is ${ }^{6}$ using a virtual representation in maintaining ideas and feeling. The maintained ideas and feeling is maintained using the language which contains words and idioms which is unique to each people who are writing, that is the art of writing. From the four skills, writing which is regarded as a form of indirect communication considered as the most complex one to master. Writing as a form of indirect communication, should be developed thoughtfully for the sake of treated the readers understanding, and so that why the target of the readers' and the choices languages should be known. Writing is the most efficiently acquired when practice in

\footnotetext{
4 Ibid., 287.

${ }^{5}$ Carol J.Orwig, [ 1998 ]"writing Skill” . Available:www Lingualink.edu.(2010, June)

${ }^{6}$ Rijlaarsdam et al.,Effective learning and teaching of writing[Boston:Springer Science+Business Media,Inc]
} 
writing parallels with practice in the other skills. Writing ${ }^{7}$ provides an excellent consolidating activity. Writing is also useful to provide exercises in the form of texts. In writing, the people need to be able to arrange statements, argumentations or comments into well-conducted paragraph or text, by using words that can be understood to make known ideas, views, or feeling to the readers, because the written form of ideas given to the readers won't be able to be taken back, and there is not any chances to add or to explain the further explanation for the reader's comments. In this case, the writer used to be careful while writing.

Process approach ${ }^{8}$ tends to focus more on the varied classroom activities that promote the development of language use. The approach involves brainstorming, group discussion, and re-writing. The general steps and sequences of the approach such as brain storming ideas, organizing ideas into mind map, spider gram, linear for, etc. The further steps then, writing the first draft, exchanging the first draft while responding to others' work, editing, revising, and finally publishing the best writing to share. However, process approach is not suitable in teaching writing monolog text of each. Process approach may help the students greatly to write specific genres like narrative, descriptive, recount, and expository.

As one of the four language skills, writing always occupies a place in most English subject matter at school based on the stated curriculum where English is taught from early primary school up to the university. Writing is one of the language skill which is important because, through writing the students are able to communicate as the productive skill in written mode. In fact there are many students who study English but they have low in writing skill. Learning English is not easy because English is not our national language. Many students in Indonesia find problems to master English, as a result most of them are not interested to learn English.

In teaching writing, teachers must creative to find out an appropriate method to make students interest because writing is very important in English language, while writing is seen to be the most attainable skill for the students in country where

\footnotetext{
7 Jack C.Richard,Second Language Writing[Cambridge:Cambridge University Press,2004]

8 Black, et al. "Assesstmen for writing:Putting it into practice" [England: Mc.Graw-Hill Education,2004]
} 
English is not a native language, this means that writing skill as one of the language skills could be a major goal of learning a foreign language or a second language.

In order to help students' activity in writing, a teacher should look for an effective technique to make learning English easier, more pleasant, and more enjoyable. To make writing easier, the technique like eclectic is supposed as one of the effective technique to improve writing skill because it is impossible to get the skill without being taught by a suitable technique. By using Eclectic method in teaching writing, it is assumed that students writing skill would be improved.

There are many learning methods that were used to investigate in teaching writing, but here two methods are mentioned. First, STAD method, that was used by Sinarti. A brief description about the method, according to Slavin (as cited in Sinarti 2012), are as follows, student are divided to four or five members that has different performance level, gender, and ethnicity. The teacher presents a lesson and then student work within their teams to make sure that all team members have mastered the lesson. Finally, the students take individual quiz on the material in which time they may not help one another. To ensure success of a teaching learning process, the lesson plan and the manner in which the step are executed will determine the outcome.

The second, Instructional method ${ }^{9}$, that was investigated by Sarah Warshauer Freedman. Instructional method has become increasingly purposeful in writing classes as ideas about the close relationship between talk and writing have been increasingly guide practice. Writing instructor have, for example: organized social interactions that supports a specific writing role, alternating teacher recitation in front of full class, with conferencing in small groups (as cited in Sarah Warshauer F 2001) . With such arrangements engage students in different ways as members of communities that motivate and respond to writing. They highlight, moreover, that writing is social even though authors typically must imagine their audiences as they compose individually.

In other side, at present eclectic method is chosen as one of the technique in teaching writing because of the students are heterogeneous and versatile level

\footnotetext{
9 Sarah Warshauer F, Instructional method and learning activities in teaching writing [New York:Macmillan
} University Press, 2001] 
intelligent in the classroom. A technique of teaching through eclectic way ${ }^{10}$ is rich of combination of multiple activities. Eclectic method emerged as an alternative method, to solve the weakness of each method. The idea of eclectic method is quoted from part of an article compiled by Haskell in selected articles from the TESOL Newsletter 1966-1983 (p,119). An eclectic methodology (or approach) is one which utilizes the best (or most appropriated and useful) parts of existing methods.

Eclectic method ${ }^{11}$ is a method of language education, than combines various approaches and methodologies to teach language depending on the aims of the lesson and the abilities of the learners. Different teaching methods are borrowed and adapted to suit the requirement of the learners. It breaks the monotony of the class. In addition, it is a conceptual approach that does not merely include one paradigm or a set of assumptions. Instead, eclecticism adheres to or is constituted from several theories, styles, and ideas in order to gain a thorough insight about the subject, and draws upon different theories in different cases.

'Eclecticism' is common in many fields of study such as psychology, martial arts, philosophy, religion and drama. There are varied approaches and methods used for language teaching in eclectic method $^{12}$, the teacher can choose from these different methods and approaches: 1) Grammar-translation method: it is a method of teaching languages by which students learn grammatical rules and then apply those rules by translating between the target language and the native language. 2) Direct Method: In this method the teacher refrains from using the students' native language. The target language is directly used for teaching all the four skills-listening, speaking, reading and writing. 3) Structural - situational Approach: In thia approach, the teacher teaches the language through a careful selection, gradation and presentation of vocabulary items and structures through situation based activities. 4) Audiolingual/Audio-visual method: In this style of teaching students are taught through a system of reinforcement. Here new words and grammars are directly taught without the students' native language. However, unlike direct method, audio lingual method does not focus on vocabulary. Instead the teacher focuses on grammar through drill

\footnotetext{
${ }^{10}$ Fachrurrazy, Teaching English foreign language for teachers in Indonesia [Bandung: Alfabeta, 2010]

11 Wilkipedia, [2015] "Eclectic Approach" (online ) Available: https://en.wikipedia.org/wiki/Eclec1[ 2016, Dec ]

12 Ibid.
} 
and practice. 5) Bilingual Method: The word “ bilingual” means two languages. In bilingual method, the teacher teaches the language by giving mother tongue equivalents of the words or sentences. This method was developed by C.J.Dodson. 6) Communicative language teaching: This approach lies emphasis on oral method of teaching. It aims to develop communicative competence in students. 7) Totalphysical Response: It is based on the theory that memory is enhanced through association with physical response. 8) The Silent Way: In this method the techer uses a combination of silence and gestures to focus students' attention. It was developed by Caleb Gattegno.

In accordance to Masum Billah stated that ${ }^{13}$ the eclectic method is the label given to a teacher's use of techniques and activities from a range of language teaching approaches and methodologies. The teacher decides what methodology or approach to use depending on the aims of the lesson and the learners in the group. Eclectic approach for teaching foreign language is commendable when circumstances do not allow for the adoption of a single method. Learners of foreign languages nowadays are prepared to invest less time than before in learning a foreign language. However, they expect to become sufficiently competent in that language in order to be able to perform well under particular circumstances. It is neither a teaching tool for the teacher nor a learning method for the learners.

Based on the result of pre-observation at SMPN 1 Keruak, there are still many students who are not able to write recount text. The students could not retell events for the purpose of informing or entertaining. They could not apply the orientation, events and re-orientation of the text. In writing a recount text, they do not understand how to state the significant lexical grammatical features of the recount monolog text. Students are not interested in learning writing. They were lazy, bored, monotony and lack of motivation if the teachers ask them to write something even it just writes a simple recount text. Those are assumed because of the applied monotony method in handling the process of teaching and learning. So that why, this study chose the adherence of constituted theories of Grammar Translation ( GTM ) and PTBK Technique to investigate its effectiveness of students' writing competency in short monolog text of recount. Based on the above phenomenon, it has

13 Masum Billah, [ 2015 ]"Eclectic Approach to Teaching Language [online]. Available http://www.observerbd.com/201 [2016, Dec ] 
investigated a study about "The Effectiveness of Eclectic Method in Teaching Writing English of Recount Text for the eight Grade Students of SMPN 1 Keruak in the school year 2016-2017".

\section{Methods}

\section{A. Research Design}

The purpose of this study was to know the effectiveness of the eclectic method to improve students' writing skill at the eighth grade of SMPN 1 Keruak in the academic year 2016-2017. The method of this research was pre-experimental method with one class. Therefore, it is needed to establish the regular instruction to one group. The group had been given the pre-test before treatment, and after the treatment the group have been given post-test to find out the effectiveness of the treatment. The design of the research was showed in figure 01 :

\begin{tabular}{lccc}
\hline Subject & Pre-test & Treatment & Post-test \\
\hline $\mathrm{E}$ & $\mathrm{O}_{1}$ & $\mathrm{X}$ & $\mathrm{O}_{2}$ \\
\hline
\end{tabular}

Figure 01

The One Group Pre-test and Post-test Design

Where :

E $\quad=$ Group of Experimental

$\mathrm{X}=$ Treatment

$\mathrm{O}_{1} \quad=$ Pre-Test

$\mathrm{O}_{2} \quad$ Post-test

\section{B. Population and Sample}

1. Population of the Study

The population of this research was at the eighth grade Students of SMP Negeri 1 Keruak in the academic year 2016-2017. The number of population 398 students consisted of eight classes.

2. Sample of the Study 
The study took only one class as the sample and respondent of this research. The number of the sample was 36 students' where chosen VIII/c by using cluster random sampling technique.

\section{Data Collection}

1. Variable Identification

a. Independent variable was eclectic method

b. Dependent variable was writing

2. Variable Definition

a. Eclectic Method Interestingly ${ }^{14}$

The Grammar Translation Method are actually not the distinctive features of GTM, since they were already well-accepted as basic principles of language teaching. What was new was the invented, graded sentences rather than authentic literary texts in order to make language learning easier. The key features ${ }^{15}$ are as follows : 1) Classes are taught in the mother tongue, with little active. 2) Much vocabulary is taught in the form of lists of isolated words. 3) Long elaborate explanations of the intricacies of grammar are given. 4) Grammar provides the rules for putting words together, and instruction often focuses on the form and inflection of words. 5) Reading of difficult classical is begun early. 6) Little attention is paid to the content of the texts, which are treated as exercises in grammatical analysis. 7) Often the only drill are exercises in translating disconnected sentences from the target language into the mother tongue. 8) Little or no attention is given to pronunciation.

The discriptions of some common typical techniques closely associated with GTM are ${ }^{16}$ : 1) Translation of a literary passage. 2) Reading comprehension questions. 3) Antonyms / synonyms. 4) Cognates. 5) Deductive application of the rule. 6) Fill-in-the-blanks. 7) Memorization. 8) Use words in sentences. 9) Composition. PTBK stands for Pelatihan Terintegrasi Berbasis Kompetensi. PTBK Technique $^{17}$ is a technique developed based on the necessity of the teacher competencies which should be owned by the English teachers in order they all gain

\footnotetext{
${ }^{14}$ Howatt,[1984"The Empirical Evidencefor the Influence of L1in Interlanguage"[online].Available:https://oswaldoipc.wordpress.

15 Prator and Celce-Murcia[1979]"'Teaching English as a Second Foreign Language"'[online]."Ibid"

16 Larser Freeman. Techniques and principles in language teaching. [With M. Anderson. Third Edition. Oxford: Oxford University Press,2000]

17 Departemen Pend.Nasional, Dirjen PDM [ Jakarta : Direktorat PLP,2005], 2
} 
the needed competency to make sure that they are able to do their best in teaching and learning process.

The steps are:1) Building Knowledge of the field : to arouse students attention, explaining the topic, generic structure and the grammatical features of the text. 2) Modeling of The Text : giving the text to the students, asking some questions about its generic structure. 3) Joint construction of the text: ask the students to work in group to do the task to make a simple text. 4) Independent construction of the text : the students ask to write the text individually refers to the social function, generic structure, and grammatical features of the text. As for example according to the recount text.

The social function of recount text ${ }^{18}$ is to retell events for the purpose of informing or entertaining. Its generic structure are: 1) Orientation : provides the setting and introduces participants. 2) Events : tell what happened, in what sequence. 3) Re- orientation : optional-closure of events. Its significant grammatical features are : 1 ) Focus on specific participant. 2) Use of material processes. 3) Circumstances of time and place. 4) Use of Past Tense. 5) Focus on temporal sequence.

b. Teaching writing"

What is teaching? . Teaching ${ }^{19}$ is the process of attending to peoples' needs, experiences and feelings, and making specific interventions to help them learn particular things. Interventions commonly take the form of questioning, listening, giving information, explaining some phenomenon, demonstrating a skill or process, testing understanding and capacity, and facilitating learning activities (such as note taking, discussion, assignment writing, simulation and practice) Writing ${ }^{20}$ is a medium of human communication that represents language and emotion with signs and symbols. In most languages, writing is a complement to speech or spoken language, Writing is not a language, but a tool developed by human society. Within a language system, writing relies on many of the same structures as speech, such as vocabulary, grammar, and semantics, with the added dependency of a system of signs or symbol. The

18 Ibid., 47.

19 Infed. Org "What is Teaching? A definition and discussion" [online]. Available: http://www.google.com/m?q=what+is.[2016, Dec]

20 Wikipedia, The Free Encyclopedia "Writing". [online]. Available: https://en.wikipedia.org/wiki/[Dec,29] 
result of writing is called text, and the recipient of text is called a reader. It can be synthesized that teaching writing is a process and intervention the students' needs through learning activities by giving information, explaining, questioning, listening, demonstrating a skill or process, testing understanding and capacity to conduct the students in gaining writing ability to produce a text.

\section{Instrument}

The instrument ${ }^{21}$ was writing test by asking the students individually to write a short essay monolog text of recount in the pre- test and the post - test.

It was a teacher made test completed by the score rubric included : content, rhetoric, language context, and the generic structure of the text. The range of the score were : 1) excellent to very good, 27 to 30. 2) good , 24 to 26. 3) fair, 21 to 23.4) inadequate, 18 to 20.5$)$ inacceptable, 0 to 17.

\section{Technique of Collecting Data}

a. Pre-test

This test applied before teaching the students by using Writing English test.

b. Treatment

The students were treated by using eclectic method.

c. Post-test

The test was given after applying treatment.

\section{Data Analysis}

The used of the data analysis was descriptive statistics to analyze the qualitative data that was gained in the pre-test and post-test. All of the process was computed by using SPSS Statistics 17 for Windows.

1. Descriptive Statistics

The descriptive statistics was used to analyze the data. The steps began by calculating the mean score of the pre-test and post-test by using SPSS Statistic 17 for Windows. The mean showed a single score that indicated students' writing skill. Then, the next step was finding out standard deviation. It was needed to calculate the degree to which the group of scored deviated from the mean. It was started by putting the analyzed data, then went to menu

${ }^{21}$ Depdiknas,Dirjen PDM,MPT Bahasa Inggris [Jakarta:Dirjen PDM Direktorat PLP 2004], 35. 
bar and selected Analyze, then selected Descriptive Statistics, the selected Descriptive and the standard deviation of the mean was automatically shown in SPSS Statistic Viewer.

2. Testing Hypothesis

a. Normality Testing

Normality testing was used to know whether or not the data had normal distribution. Before testing the hypothesis, the normality test for the data had to be conducted first. To find out the normal distribution, it was opened the entering data then went to analyze. The next step was selecting nonparametric test then 1-sample K-S. In One-Sample Kolmogorov-Smirnov Z dialog box, then it was selected the variables from the left to variable on the right. It was continued by putting a tick in the box of normal of test distribution then OK. As the result, the output of OneSample Kolmogorov-Smirnov Z was displayed in SPSS Statistic Viewer. If ${ }^{22}$ the values of the significance level of investigation variables are greater than 0.05 , the distribution of the data is normal.

b. Homogeneity

After calculating the normal distribution of the data, the next step done was checked the homogeneity of the variance of the variables. It was begun by going to Analyze, then compares Means, and then One-Way ANOVA. In One-Way ANOVA dialog box, it was selected the variables then clicked on option. It was continued by putting a tick in homogeneity of variance test in option box. As the last step, it was clicked ready then OK. The result of homogeneity of variance test displayed. If ${ }^{23}$ the values of the significance level of the investigation variables are greater than 0.05, the variance of each variable was homogeneous (Moedjito, 2014).

c. Testing Hypothesis

To analyze the hypothesis testing which aimed at knowing whether the alternative hypothesis was accepted or not, the application of SPSS 17 was used to know the effectiveness of the eclectic method in teaching writing from experimental group. To begin with, it was opened the data that would be calculated the continued by going to menu bar and choosing Analyze menu, then selecting Compare Means, and then clicked Paired Samples t-test. In Paired Sample t-test dialog box, it was

22 Moedjito, Basic Statistics for Research in Language Education. [Selong: STKIP Hamzanwadi Selong, 2013] 23 Ibid. 
selected the variables to be tested. As the output, the SPSS statistic showed the result of the procedure which indicated that the hypothesis was accepted or rejected.

\section{Finding And Discussion}

\section{A. Result}

1. Descriptive Statistic

The research finding in this study was description about the effectiveness of the eclectic method to improve students' writing skill at the eighth grade of SMP Negeri 1 Keruak in the academic year 2016-2017. The data of pre-test and post-test was gained from the experimental group by using eclectic method which consisted of 36 students and the score interval that were used to determine students' writing skill was 4-15. So, the minimum score was 4 and the maximum score was 15 .

Based on the data gained, the highest score on pre-test was 10 and the lowest score was 4 with the mean score 7.21, standard deviation was 3.16 and variance was 9.95, while on post-test, the highest score was 15 and the lowest score was 6 with the mean score was 9.25, standard deviation was 2.77 and variance was 7.67. The gained data showed that there was an increase in writing skill of the students after the treatment was given by using eclectic method. It was indicated by mean score of the post-test that was higher than the pre-test . To be clearer, it can be seen on Table 03 .

Table 03

Students' score on pre-test and post-test

\begin{tabular}{cccc}
\hline \multirow{2}{*}{ Test } & & Pre-Test & Post- \\
\hline $\mathrm{N}$ & & \\
\hline $\mathrm{x}$ & 36 & 36 \\
\hline $\mathrm{S}$ & 7.21 & 9.25 \\
\hline $\mathrm{s}^{2}$ & 3.16 & 2.77 \\
\hline
\end{tabular}

Where:

$\mathrm{N} \quad=$ number of students

$\mathrm{x} \quad=$ mean score

$\mathrm{s} \quad=$ standard deviation

$\mathrm{s}^{2} \quad=$ variance 
Based on the data in table 03 , it could be seen that there was a difference between students' writing score after and before the treatment was implemented. Mean score of the students' after teaching by using eclectic method was higher than mean score of the students' before treatment was implemented.

2. Testing Hypothesis

a. Normal Distribution Test

Normal distribution test is needed in order to find out whether the data is in normal distribution or not. The normal distribution data indicated that the sample of the study was taken from the population that had normal distribution. If the value of the significance level of the investigated variable is higher than 05 , it means that implied distribution of data was normal. The result of normal distribution test was shown on Table 04.

Table 04

The Calculation of Normal Distribution Test

\begin{tabular}{lcc}
\hline \multicolumn{3}{c}{ One-Sample Kolmogorov-Smirnov Test } \\
\hline \hline $\mathrm{N}$ & Pre-Test & Post-Test \\
\hline Kolmogorov-Smirnov Z & 36 & 36 \\
\hline Asymp. Sig.(2-tailed) & .991 & .976 \\
\hline
\end{tabular}

Based on the output data of normal distribution test by using One-Sample Kolmogorov-Smirnov $\mathrm{Z}$ test as shown on table 04, the value of the Asymp. Sig. (2tailed) on the pre-test and post-test was higher than 05. It indicated that the data was in normal distribution.

b. Homogeneity Test

After knowing that the sample was in normal distribution, the next was counting the homogeneity test. The homogeneity test was calculated by using OneWay ANOVA test. It was used to find out whether the data was homogenous or not. If the significance level of the data was higher than .05 , it meant the data was homogenous. But if the was lower than .05 , it meant the data was not homogenous. The result of the homogeneity test was shown on Table 05. 
Table 05

Test of Homogeneity of Variance

\begin{tabular}{|c|c|c|c|c|}
\hline & \multicolumn{4}{|c|}{ Pre-post test } \\
\hline & \multicolumn{4}{|l|}{ Levene } \\
\hline & Statistic & df1 & df2 & Sig. \\
\hline Score based & .424 & 5 & 19 & .826 \\
\hline
\end{tabular}

Based on the data that was shown on Table 05, it can be seen that the significance level of data was .826. It was higher than 05. It means that the data was homogenous.

c. Hypothesis Test

Based on normal distribution and homogeneity test that had been done, it showed that the data was normal and homogenous, so it was continued by doing the hypothesis test by using Paired Sample t-test. In the hypothesis testing by using Paired Sample t-test, it was found that the confidence interval of the difference was $95 \%$ and the standard significance (2-tailed) value level was 05.

If the significance (2-tailed) value level of the analyzed data was lower than 05, it means the alternative hypothesis $(\mathrm{Ha})$ is accepted and the null hypothesis $(\mathrm{Ho})$ is rejected. But if it is higher than 05 the alternative hypothesis $(\mathrm{Ha})$ is rejected and the null hypothesis (Ho) is accepted. Result of hypothesis test by using PairedSample t-test was shown on Table 06.

Table 06

Hypothesis Test by Using Paired-Sample T-Test

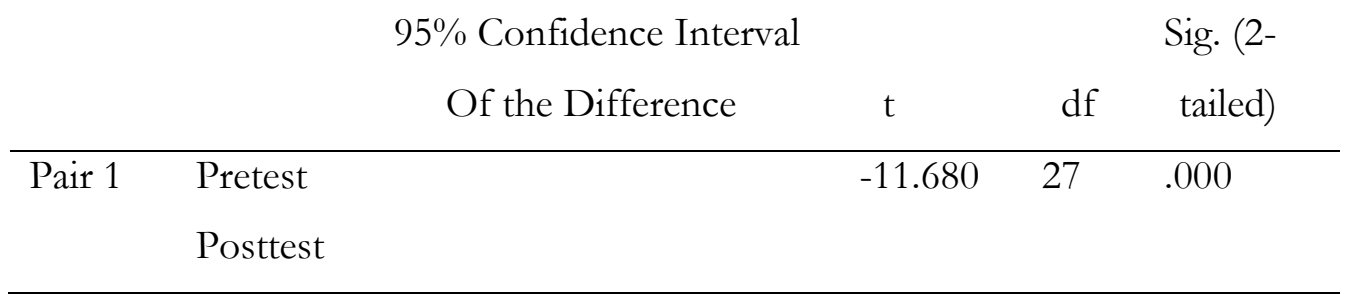

The data on table 06 showed the significance (2-tailed) tailed value level of the analyzed data was 000 . It is lower than 05 , so it means that the alternative hypothesis $(\mathrm{Ha})$ was accepted and the null hypothesis $(\mathrm{Ho})$ was rejected. 


\section{B. Discussion}

It was elaborated that the result of this research which using Eclectic method was effective in teaching writing to the eighth grade in the academic year 2016-2017. The first statement of the problem proposed in the previous chapter "Is eclectic method effective in writing skill at the eighth grade of SMP Negeri 1 Keruak in the academic year 2016-2017?" The result analysis on the effectiveness of the eclectic method in writing skill was presented in the table descriptive statistic on experimental group. The students became more active in the class, the students became more confidence to communicate through writing with the other friends by using English.

As what has been described above, that the design of this research wasone group pre-test and post-test design. Therefore it was concerned about gaining the qualitative data through pre-test and post-test in order to figure out the effectiveness level of the given treatment to the subject of the study.

In this research, the meeting was conducted for 8 times, 4 times meeting for treatment by using eclectic method and 2 times meeting for pre-test, and than 2 times meeting for post-test. The mean score of the pre-test was 7.21 and the standard deviation was 3.16. While the mean score of the post-test was 9.25 and the standard deviation was 2.77. It meant, the result of the post-test was higher than the pre-test. While the result of t-test by using paired sample t-test showed that the eclectic method was significantly effective in writing skill to the students of SMPN 1 Keruak in the academic year 2016-2017.

The result of this study was in lined with ${ }^{24}$ what had been mentioned by Krashen that the purpose of learning language is to be able to communicate whether in oral or written form. This natural way of communication can be applied in writing class by doing the steps of pre writing, drafting, revising, and editing, through building knowledge of the field, modeling of the text, join construction of the text, and independent construction of the text.

\section{Conclusion, And Implication}

Based on the data analysis, the finding, and the discussion it was presented the conclusion, implication, and suggestion.

${ }^{24}$ Krashen, S. D. Foreign Language Education The Easy Way. [Culver City E, CA: Language Education Associates, 1997] 


\section{A. Conclusion}

It can be concluded that the conclusion of this study was that the mean score of post-test was higher than the pre-test and the result of t-test by using paired sample t-test showed that significance value level was lower than .05. It means that the eclectic method was significantly effective in writing skill for the eighth grade of SMPN 1 Keruak in the academic year 2016-2017.

\section{B. Implication}

The implication of the research findings have been described are as follows: The eclectic method was significantly effective to be implemented in English writing class to improve the students' writing skill. By using eclectic method, the teacher could stimulate students' creative in writing English learning. Eclectic method was not only effective to be used, but also helps the students to be more active and creative in the learning process of writing. It enables the students to make reflection on their strengths, progress, and weaknesses when producing their writing learning so that the students can monitor their learning progress. Besides, it was found that there was a warm atmosphere of the class, the students are active learners in the learning process, rather than recipients of information since they are engaged in learning by doing. The learning outcomes is higher than before as they have treated by using eclectic method.

\section{Bibliography}

Billah Masum. 2015. Eclectic Approach to Teaching Language. Retrieved from http://www.observerbd.com/201. Visited on, Dec 2016

Black, Paul, Christine Harison, Clare Lee, Bethan Marshal, and Dylan Wiliam. 2004. Assessment for Writing: Putting it into Practice. England: Mc Graw Hill Education.

Depdiknas,Dirjen PDM. 2004. Materi Pelatihan Terintegrasi Bahasa Inggris. Jakarta: Dirjen PDM Direktorat Pendidikan Lanjutan Tingkat Pertama.

Departemen Pend. Nasional, Direktorat Jendral Pendidikan Dasar dan Menengah. 2006. Lampiran 2 Permendiknas Nomor 22 Tabun 2006. Jakarta: Direktorat Pendidikan Lanjutan Tingkat Pertama.

Freeman, Larser. 2000. Techniques and principles in language teaching. With M Anderson. Third Edition. Oxford: Oxford University Press. 
Fachrurrazy. 2010. Teaching English foreign language for teachers in Indonesia. Bandung: Alfabeta.

Howatt,1984. The Empirical Evidencefor the Influence of L1in Interlanguage. Retrieved from https://oswaldoipc.wordpress. Visited on December 2016.

Infed.Org. 2016. What is Teaching? A definition and discussion. Retrieved from http://www.google.com/m?q=what+is. Visited on December 2016.

Krashen, S. D. 1997. Foreign language education the easy way. Culver City E, CA: Language Education Associates.

Lampiran 2 Permendiknas No.22. 2006. Latar Belakang, Tujuan, Ruang Lingkup, Standar Kompetensi, dan Kompetensi Dasar B.Inggris SMP/M.Ts. Jakarta:Dirjen PDM Direktorat Pendidikan Lanjutan Tingkat Pertama.

Moedjito. 2013. Basic Statistics for Research in Language Education. Selong: STKIP Hamzanwadi Selong.

Orwig, Carol.J. 1998. Writing Skill . Retrieved from:www Lingualink.edu. Visited on June 2014.

Prator and Celce-Murcia. 1995. Communicative Competence: A pedagogically Motivated Model With Content Specifications. Retrieved from http://escholarship.org /uc/item/2928w.Visited on December 2016.

Richard,Jack C. 2004. Second Language Writing. Cambridge:Cambridge University Press.

Rijlaarsdam et al.,Effective learning and teaching of writing. Boston:Springer Science+Business Media,Inc

Sarah Warshauer F. 2001. Instructional method and learning activities in teaching writing . New York: Macmillan University Press.

Wikipedia. 2015. Eclectic Approach .Retrieved from https://en.wikipedia.org/wiki/Eclec1. Visited on December 2016.

Wikipedia. 2016. The Free Encyclopedia" Writing". Retrieved from https://en.wikipedia.org/wiki/writing. Visited on November 2016. 